Journal of Political Science
(A Peer-Reviewed, Open Access Journal and Indexed in NepJOL)
ISSN 2362-1273 (Print); ISSN 2773-8132 (Online)
Volume 21, Special Issue, August 2021
http://ejournals.pncampus.edu.np/ejournals/jps/
Published by
Department of Political Science, Prithvi Narayan Campus, TU, Pokhara, Nepal
Email: polsc@ @ncampus.edu.np; URL: www.pncampus.edu.np

\title{
Conceptual and Theoretical Debates on Social Movement Studies
}

\author{
Mahendra Sapkota, PhD \\ Central Department of Rural Development \\ Tribhuvan University, Kirtipur
}

Corresponding Author: Dr. Mahendra Sapkota, Email: sapkota.mahendra27@gmail.com

DOI: https://doi.org/10.3126/jps.v21i1.39280

Copyright 2021@ The Publisher and Author/s. The journal is licensed under a Creative Commons Attribution-ShareAlike 4.0 International License.

(c) (i) (?)

Submitted 30 June 2021; Reviewed 5 July 2021; Accepted 10 July 2021; Published 20 Aug. 2021

\begin{abstract}
This paper is a review based synthesis on the conceptual and theoretical debates on social movements (SMs). It aims to analyse the debate from different theoretical lens which are popularly used in the studies of SMs. The paper then explores prominent research issues that could be grounded at the local contexts of the movements. The main argument of the paper is that the discourse of SM is not linear and monolithic. Rather, it is a poly centric notion and thus essentially contested in terms of theorization and research.
\end{abstract}

Keywords: Collective identity, social movement, movement theories, research implications

\section{Introduction}

Social movements are a type of group action or collective behaviour. The term 'social movement' was introduced in 1850 by the German sociologist Lorenz von Stein in his book History of the French Social Movement from 1789 to the Present (1850). In this work he diffused an idea of Marx's class consciousness. However, there is no consensus within academics to trace out the history of SMs. For example, Scott and Marshall (2009, p. 704) presents "the term social movement was first used by Saint-Simon in France at the turn of the $18^{\text {th }}$ century, to characterize the movements of social protest that emerged there and later elsewhere, and was applied to new political forces opposed to the status quo". 


\section{Conceptual and Theoretical Debates on Social Movement Studies}

With the growing dynamics of social changes and modernization, the discourse of social movement is becoming popular, and perhaps a never avoidable disciple of social sciences. This is why the 'modern society' has become a 'social movement society' (Meywer \& Tarrow, 1998), and the twenty-first century as a time of mobilization for social change (Taylor, 2000; Sapkota, 2017). However, the notion of social movement is conceptually divergent and methodologically contested (Della Porta, 2014).

Majority of scholars suggest social movement to mean as an organized group of people involved in a conflict with clearly identified opponents, sharing a common identity, a unifying belief or a common program and active collectively to promote or resist the social change in their society. Mario Diani views the different understandings of social movements and tries a synthesis including all relevant aspects. He defines a social movement as " $a$ network of informal interactions between a plurality of individuals, groups and/or organizations, engaged in political or cultural conflict, on the basis of shared collective identity" (Diani, 2002, p. 165). This definition suggests collective identity as an important dimension of social movements, but recent publications start to contest this. Empirically, collective identity implies a degree of homogeneity and stability that is not appropriate anymore in a time when sociology uses new concepts such as networks, flows and complexity. Taking these discussions into account, Bebbington rightly proposes that:

a social movement is a form of collective action but it is not itself an actor, rather it is a process, sustained by a set of actions and actors, in which what prevails is an action motivated by shared grievances and senses of injustice, and therefore by a vision - perhaps not specified - of the need to find another way of organizing society and thinking about development $(2009$, p. 8$)$.

Defining what a movement is, what constitutes it, what its qualities are, has been a major undertaking for social movement theorists, the blurred edges of where a movement ends who is 'in' or 'out'- mean that definitions are fraught with problems. It has change-oriented goals or claims; performs some extra-legal or non-institutional collective action; has some degree of organization and a degree of temporal continuity (Karki, 2012). The leadership, ideology and networks other some of the other important dimensions of SMs. Of course, these are overlapping and to some extent, interdependent in one hand and contradictory on the other hand. All of these definitions have been extremely useful in enabling the SM researcher to 'decode' the movements at the preface of local contexts, networks and framing.

\section{Social Movements Research}

Social movements have been historically rooted in and crossed with different political regimes and mass campaigning. It is evident that the early growth of social movements was connected to broad economic and political changes in the European countries including the notions of parliament, proletarian, market and capitalization. Empirically, the number and quality of studies of social movements in Latin America has grown steadily since the early 1980s though urban popular movements have figured prominently among those studies. In this regard, Tilly (2004) takes the history of social movements as a series of contentious performances, displays and campaigns by which ordinary people made collective claims on others (p. 12). He argues that the movements are the major vehicle for people's participation in public politics; though he is less concerned with the modern elements of public politics and collective claims. 


\section{Conceptual and Theoretical Debates on Social Movement Studies}

In recent years, increasing attention is being paid to feminist movements (Baksh-Soodeen, \& Harcourt, 2015), ethnic movements (Oliver, 2017), religious movements (Barker, 2016) and grassroots movements of various kinds (Vandevoordt \& Fleischmann, 2021). On the other hand, few studies exist of the LGBT movements (McKenna, \& Chughtai, 2020) and ecology movements (Foster, 2017). Human rights and defence of life issues, as well as youth forms of protest, have been important in a few countries. Civic movements of various kinds and regional movements complete the list of the most visible movements as they have appeared until today in Latin American scholarly and political literature. It got popularized worldwide with the fall of colonialism, rise of socialist movements, end of cold war, and recently with the increase of development maladies around the world. The study of SMs in Europe is increasingly popular (Célia, 2020), and it also bears a huge scope in Latin American context (Borda, 2018; Escobar \& Alvarez, 2018). However, less scholarly interest has been paid in analysing the history of social movements in particular context of Asian and south Asian countries. The south Asian concerns have increased significantly in recent years and a number of academic discussions and debates are emerging. Some Indian scholars (e.g. Shaha, 2004, Abraham, 2017; Kothari, 2011) and a few European scholars (e.g. Amin et al., 2009; Frank \& Fuentes, 2011; SinghaRoy, 2010) have worked in this regard. In Nepal, a few scholars engage in the studies of SMs, though the contemporary literature is influenced much with identity politics, Madhes movement and caste/ethnic movements (Dahal, 2004, Karki, 2012; Sapkota, 2014; Paudel, 2016).

\section{Theoretical Approaches of Social Movements}

Epistemologically, studies on social movements follow either a Marxist or a non-Marxist framework for analysis. The scholarly work of SMs was initiated with the work of Marx and his colleague Engels both in European and North American traditions (Crossley, 2009; Tarrow, 2011). Marxists scholars are primarily interested in bringing about revolutionary changes in society. According to them, the causes for social movement are located in the economic structure of society. Antagonistic interests between the bourgeoisie and working classes are inherent in a class-based society which generates contradictions and the spaces for social movements (Barkar, 2013; Marx, 2000). Yet, the scholars stand upon multiple views in analysing which class and what kind of consciousness in modern society could be the potential to be a vanguard to lead revolutionary social movements. Moreover, it seems deterministic in economic terms. Being based on these two criticisms, New-Marxist scholars stand that the social movements in Marxist ideology should be reviewed in the changing power relations and class structure which could address the issues of gender, identity and autonomy of contemporary societies (Amin et al., 2009). Though this tradition became popular after the demise of Soviet Block since the early 1990s, it is ideologically divided into different versions and variants.

On the similar context, some Indian critical theorists raised the issues of subaltern studies in 1980s which insisted on the rewriting of the history in the name of the historically avoided groups, i.e. the subalterns (Guha \& Spivak, 1988). The subaltern movement became a discourse of social movements, particularly in South Asian societies and few in Latin American post-colonial communities, though it remained only as academic discourse rather than being empirically campaigned (Majumdar, 2015). Very recently, Eimer (2020) has analysed the subaltern studies in terms of political agency taking the specific cases of Brazil and India. Some others also criticized that the study has been captured by the elites and well-offs, levelling it as a decline of subalterns in the subaltern studies (Sarkar, 2014). In context of Nepal subaltern movement is neither organized nor established institutionally. It 


\section{Conceptual and Theoretical Debates on Social Movement Studies}

is unfortunately a failed dream for the emancipation of subaltern masses in Nepali society, which are particularly the rural women, poor farmers, minority groups, Dalits, and bonded labours (including freed Halyas, Kamaiyas and Kamlharies).

On the other hand, the non-Marxist views upon the SMs are rooted on the structuralfunctional school of thought. Structural functionalists perceive society as a whole of system. They argue that societies, when function properly, seem to be self-regulating given that every part of society must have a function in relation to the regulation and maintenance of society as a whole (Giddens, 2009). The structural-functional approach of social movement is essentially a non-Marxist, and the group of theories under this domain can be categorized as the classical model of social movement which entail structural strains and deprivations as the 'function and structure' of the SMs. There is a great deal of variation amongst the nonMarxist scholars also, in their approach to analysing social movements. The ideological positions regarding a need for social and/or political change, and the role of movements therein differ. Within this tradition, Melucci (1996) portrays the theoretical differentiations between Europe and the United States and says that in reaction to the structural functionalist model in USA, three major perspectives emerged: collective behaviour (in its interactionist version), resource mobilization and political process positing the question of 'how' collective action emerged and was carried out. Meanwhile, as a critique to Marxist theory, there developed the new social movements (NSM) theory in Europe.

\section{Classical Model (CM) of SMs and Collective Behaviour}

The classical model of social movements refers to a set of theories with a common denominator: they all start from the notions of 'structural strain' or 'breakdown'. This kind of structural strain in society induces the breakdown of social order to promote disruptive psychological state that finally forms the background of 'social movement' (McAdam, 1982, p. 7). Earlier literatures of Durkheim (in terms of social differentiation and division of labour, 1964), Smelser (theory of collective behaviour, 1962), Wallace (theory of revitalization, 1956), Turner and Killian (theory of mass society, 1987) and Gurr (theory of relative deprivation, 1993) all describe different notions of classical approaches of SMs. Following this, collective behaviour theory was developed in early 1970s. From the structural functional school, the theory portrays movement emergence as a reflex response to 'grievances', 'deprivations', 'anomie', 'structural strains', or other such forms of hardship.

Nevertheless, there are many flaws in these approaches, and it has been well articulated by various sociologists and political scientists. First, they do not take SMs as purposeful phenomena. Second, there is not a detailed explanation devoting much attention to the structural origins of conflicts (Della Porta \& Diani, 2015). Relative deprivation is increasing throughout most of the underdeveloped countries where there is revolution on expectations, desires and hopes but it does not match with the realization of development outcomes in people's daily life. The theory is largely engaged on psychological motives rather than the ideological and socio-cultural sources. Oommen (1977) argues that the deprivation theorists view movements as 'temporary aberrations' rather than as 'ongoing processes of change'.

\section{Resources Mobilization Model (RMM)}

Resource Mobilization (RM) theory signalled a development in SM theory by a new generation of social scientists in the sixties. According to RM theory, social movements, 


\section{Conceptual and Theoretical Debates on Social Movement Studies}

like other organizations, collect, trade, utilize (and waste) resources in their activities (McCarthy \& Zald, 1977; John \& Mayer, 2017). These resources may be members, money, votes, information, trust, jobs, guns, and image(s) (Goldberg, 1991, p. 7-8). RM theorists moved much of the attention of social movement investigators towards the rationality of social movement organizations who "weigh the rewards and sanctions, costs and benefits, which alternative courses of action represent for them" (Oberschall, 1973, p. 29). Recent contributions to the resource mobilization field have returned to an emphasis on individual social movement members who are theorized largely as rational actors who calculate the benefits and costs of social movement membership and activism.

However, given its stress on organizational rationality, resource mobilization perspectives are often criticized for concentrating on the form of social movements rather than on their content (Mueller, 1992) and for sometimes recasting movement participants as 'ultrarationalistic actors devoid of feeling' (Hunt \& Benford, 2004, p. 103). RM theory, say critics, has also treated protest as more organized than it actually is, though they could affect the success and failure of the movement (see Piven \& Cloward, 1977, 1995). The critics also cite numerous examples of resources which have enabled activists to mobilize and sustain activist networks over time. The strength of the community, followed action, shared trust, maintained group responsibility, etc. have become resources in contemporary social movements. However, who controls the resources and who leads the movement is less answered in this theoretical approach.

\section{Political Opportunity Structures (POSs)}

In SM literature, political process or opportunity theory focuses on the political and institutional environment. In resisting a given political order, SMs interact with actors who enjoy a consolidated position in such an established order of the society. According to many scholars, the concept which has had the greatest successes in defining the properties of the external environment relevant to the development of SMs is that of political opportunity structures (Della Porta \& Diani, 2006; Kriesi, 1995). A common theme in much POS literature is the fact that such political opportunities can be both open and closed, and both these case scenarios can trigger mobilization. In this context, Tarrow (2004) argues that "challengers who seize political opportunities in response to openings in the polity are the catalysts for social movements and cycles of contention" (p. 72).

Very pragmatically, the theory has seen SMs as extensions of institutionalized actions and have restricted their focus to movements of institutional change that attempt to alter 'elements of social structure and/or the reward distribution of society' (McCarthy \&Zald, 1977, p. 1218). However, field observations of the researcher have identified many instances of how activists have perceived an opening/closure in their political opportunities and have mobilized accordingly. Intertwined with this is his feeling that social actors always consciously choose to mobilize at certain times because they have evaluated the chances for success/failure. Like in the RM theory, the researcher got this cost-benefit approach of mobilization theoretically misleading and less attainable.

\section{'New' Social Movements (NSMs)}

"New" social movements are generally viewed as evolving in the 60's and 70's within the foundation of structural paradigm of the European scholars (Touraine, 2000 and Melucci, 1989 to mention in particular). It developed in response to the limitations of, or as a critique 


\section{Conceptual and Theoretical Debates on Social Movement Studies}

on resource mobilization and Marxist theories to explain collective action. According to Somerville (1997), the proponents of the NSM approach address the shifting character of Western capitalism into various dimensions and critique the conventional Marxist approach of economic determination. Accordingly, NSMs worked outside formal institutional channels and emphasized lifestyle, ethical, or identity concerns. They were new in terms of strategies, networks; and new even in comparison to conventional liberalism with its assumption of fixed individual identities and interests (Scott, 1990). Perhaps the key point made by both Melucci and Touraine in the context of the NSM debate is that sites of power have become more plural in modern societies so that its multiplicity of sites is made visible.

However, some of critical theorists of neo-Marxist school (e.g. Jurgun Habermas, Louis Althusser, AG Frank and Samir Amin) heavily criticized the NSM in terms its deviation from class and economic structure of society. The first thesis among the nine theses of SMs as proposed by Frank and Fuentes $(2011$, p. 32) asserts that 'the new social movements are not new, even if they have some new features, and the 'classical' ones are relatively new and perhaps temporary". Further, there is a tendency to describe 'new' social movements as being focused on culture and identity rather than other aspects of political life and regime changes. As Seel et al. (2000) note “...since all movements develop their own identity, common values and culture, it seems unjustified to see older social movements as materialist and NSMs as concerned solely with identity..." (p. 11). Many of other theorists found this categorization problematic, and lamented how the ideology of new social movement has been distorted with the identity politics in recent years (Gusfield, 2009).

\section{The Framing of Collective Identity}

The theorists involving in the collective identity discourse of SM are highly concerned with the causes of political action, on the internal drives which cause people to act collectively the cognitive aspects of mobilization. In many ways Melucci's concept of movement collective identity seems to exactly capture the fluidity, diversity and contradictions, and the simultaneous sense of "us", "we believe in this", inherent in the ethnic movement's ideology. He argues that collective identity is always plural, ambivalent, and often contradictory (Melucci, 1996, p. 71-78). The construction of "we" is changeable and highly contested as activists seek to delineate who "we" are (and are not) (Whittier, 1995, p. 56). In many ways, action is the key to generating movement praxis and collective identity - whilst as Steinberg (1998) points out, it is through discourse that ideas are generated; it is often discourse about action.

Collective Identity has provided a useful frame to decode the social movements. With regard to the last quote above, Melucci seems to be emphasizing something which the researcher's field study also evidenced, that movements have a pragmatic approach to the generation of movement knowledge, and that this is the way SMs develop. However, collective identity has its limits with locally constructed roots and forms of the identities.

\section{Conclusion and Research Implications}

As explained in the above review of literatures about the conceptual and theoretical debates on social movements, we can conclude that there is a huge scope of movement studies. It bears a multiple claims and counterclaims in terms of causes, actors, strategies and the impacts of movements in society. As a discourse social movement studies has gained 


\section{Conceptual and Theoretical Debates on Social Movement Studies}

attention in sociology, political science, gender studies and development studies. Thus, it includes a three-folded implications in research.

First, researches are implicitly calling to understand and analyse the dimensions, causes and characteristics of SMs. It captures the volatility and dynamism of the movements in contemporary societies. Second, it then offers a need of analysis and exploration of the agendas and issues of the movements regarding social, political and economic sphere of the people's livelihood. Third, it then eventually an alarming research issue to have a comprehensive and critical analysis about the claimed (against the perceived) achievements of the movements. It is thus required to engage research projects about the impact and effectiveness of the movement and the way people perceive it in meeting their well-being of day-to-day lives.

\section{References}

Abraham, A. (2017). Making sense of contemporary social movements in India. In The New Global Politics. 221-233. Routledge.

Amin, S., Arrighi, G., Frank, A. G., \& Wallerstein, I. (2009). Transforming the revolution: Social movements and the world system. Aakar Books.

Baksh-Soodeen, R., \& Harcourt, W. (Eds.). (2015). The Oxford handbook of transnational feminist movements. Oxford University Press.

Barker, C. (2013). Marxism and social movements. Blackwell Publishing Ltd.

Barker, E. (Ed.). (2016). Revisionism and diversification in new religious movements. Routledge.

Bebbington, A. (2009). Poverty reduction and social movements: A framework with cases. Background paper for UNRISD's poverty report. University of Manchester.

Borda, O. F. (2018). Social movements and political power in Latin America. In The making of social movements in Latin America. 303-316. Routledge.

Célia, T. S. (2020). Social Movements in Europe, from the Past to the Present. European Journal of Social Science Education and Research, 7(3), 17-26.

Crossley, N. (2009). Making sense of social movements. Prem Rawat for Rawat Publications.

Dahal, D. R. (2004). New social movements in Nepal. The Organization, June-July 2004, 3 (4), 45-59. http://www.nepaldemocracy.org/ civic_education/Social\%20 Movements.pdf

Della Porta, D. (Ed.). (2014). Methodological practices in social movement research. Oxford University Press.

Della Porta, D., \& Diani, M. (2006). Social movements: An Introduction (first edition published in 1999). Blackwell Publishing. https://www.hse.ru/data/2012/ 11/03/ 1249193172/Donatella_Della_Porta_Mario_Diani_Social_Mov.pdf 


\section{Conceptual and Theoretical Debates on Social Movement Studies}

Della Porta, D., \& Diani, M. (Eds.). (2015). The Oxford handbook of social movements. Oxford University Press.

Diani, M. (2002). Network analysis. Methods of social movement research. 173-200. University of Minnesota Press.

Eimer, T. R. (2020). What if the subaltern speaks? Traditional knowledge policies in Brazil and India. Third World Quarterly, 41(1), 96-112. https://www.tandfonline.com/ doi/pdf/ $\underline{10.1080 / 01436597.2019 .1650639}$

Escobar, A., \& Alvarez, S. E. (2018). Introduction: theory and protest in Latin America today. In The making of social movements in Latin America (pp. 1-16). Routledge.

Frank, A.G., \& Fuentes, M. (2011). Nine theses on social movements. In Shaha, G. (ed), Social Movements and the State, 32-55. Sage.

Foster, J. B. (2017). The long ecological revolution. Monthly Review, 69(6), 1-16. http://www.thebellforum.net/forums/viewtopic.php?t=79

Giddens, A. (2009). Sociology $\left(6^{\text {th }}\right.$ edition). Cambridge: Polity Press. https://ia800206.us.archive.org/15/items/Sociology 6 edition/Sociology 6 edition.pdf

Goldberg, R.A. (1991). Grassroots resistance: Social movements in 20th century America. Wadsworth Publishing Company.

Guha, R., \& Spivak, G. (1988). Selected subaltern studies. Oxford University Press.

Gusfield, J. R. (2009). New social movements: From ideology to identity. Temple University Press.

Hunt, S. A., \& Benford, R. D. (2004). Collective identity, solidarity, and commitment. In D.A. Snow, S. A. Soule, \& H. Kriesi (Eds.), The blackwell companion to social movements. 433-457. Oxford, UK: Blackwell Publishing Ltd.

John, D. M., \& Mayer, N. Z. (2017). Resource mobilization and social movements: A partial theory. In Social movements in an organizational society.15-42. Routledge.

Karki, M. B. (2012). Political doctrines and collective identities in Nepal. Contributions to Nepalese Studies: Special issue of monism, multiculturalism and pluralism from social exclusion and inclusion perspectives), 39 (1), 33-72

Kothari, R. (2011). Masses, Classes and the State. In G. Shaha (Ed.), Social Movements and the State, 68-90. Sage.

Kriesi, H. (1995). The political opportunity structure of new social movements: Its impact on their mobilization. In J. C. Jenkins \& B. Klandermans (Eds.), The politics of social protest: Comparative perspectives on states and social movements.167-198. University of Minnesota Press.

Majumdar, R. (2015). Subaltern studies as a history of social movements in India. South Asia: Journal of South Asian Studies, 38(1), 50-68.

Marx, K. (2000). Karl Marx: Selected writings. Oxford University Press.

Journal of Political Science, Vol. 21, Special Issue, August 2021 [1-10] 


\section{Conceptual and Theoretical Debates on Social Movement Studies}

McAdam, D. (1982). Political process and the development of black Insurgency, 19301970. Chicago: University of Chicago Press.

McCarthy, J. D., \& Zald, M. N. (1977). Resource mobilization and social movements: A partial theory. American journal of sociology, 82(6), 1212-1241.

McKenna, B., \& Chughtai, H. (2020). Resistance and sexuality in virtual worlds: An LGBT perspective. Computers in Human Behavior, 105, 106-199. https://ueaeprints.uea.ac.uk/ id/eprint/72982/1/Accepted_Version.pdf

Melucci, A. (1989). Nomads of the present: Social movements and individual needs in contemporary society (edited by J. Keane and P. Mier). Hutchinson Radius.

Melucci, A. (1996). Challenging Codes: Collective Action in the Information Age. xii-441. Trinity, Cambridge University Press.

Meyer, D. \& Tarrow, S. (1998). A Movement Society: Contentious Politics for a New Century. In D. Mayer, S. Tarrow (Eds.), The social movement society: Contentious politics for a new century. Rowman and Littlefield.

Mueller, C.M. (1992). Building Social Movement Theory. In A.D. Morris, \& C. McClurg Mueller (Eds.), Frontiers in Social Movement Theory. Yale University Press.

Oliver, P. (2017). The ethnic dimensions in social movements. Mobilization: An international quarterly, 22(4), 395-416.

Oommen, T. K. (1977). Sociological issues in the analysis of social movements in independent India. Sociological Bulletin, 26(1), 14-37.

Paudel, D. (2016). Ethnic identity politics in Nepal: liberation from, or restoration of, elite interest? Asian Ethnicity, 17(4), 548-565.

Piven, F. F., \& Cloward, R. A. (1995). Collective protest: A critique of resourcemobilization theory. In Social Movements.137-167. Palgrave Macmillan.

Piven, F. F., Cloward, R. A. (1977). Poor people's movements: Why they succeed, how they fail. Pantheon Books.

Sapkota, M. (2014). Emerging ethnic movements and contested rural development in Nepal. Contested development in Nepal: Experiences and reflections, 77. https://www.researchgate.net/profile/Bishnu-Upreti-2/publication/269166065 Contested Development_in_Nepal_Experiences_and_Reflections/links/54830e1a0cf25dbd59eb096f/C ontested-Development-in-Nepal-Experiences-and-Reflections.pdf\#page $=90$

Sarkar, S. (2014). Subalternity in and out of time, in and out of history. 91-109. Ashgate Press.

Scott, A. (1990). Ideology and new social movements. Unwin Hyman.

Scott, J., \& Marshall, G. (2009). A dictionary of sociology. Oxford University Press.

Seel, B. (1999). Strategic identities: Strategy, culture and consciousness in the new age and road protest movements. An unpublished $\mathrm{PhD}$ thesis, Keele University, UK. 


\section{Conceptual and Theoretical Debates on Social Movement Studies}

Shah, G. (2004). Social movements in India: A review of literature. SAGE Publications.

SinghaRoy, D. K. (2010). Changing trajectory of social movements in India: towards a holistic analytical perspective. In D.K. SinghaRoy (Ed.), Dissentive voices and transformative actions - social movements in a globalized world .135-188. Manohar Publishers and Distributors.

Somerville, J. (1997). Social Movement Theory, Women and the Question of Interest. Sociology, 31(4), 673-695.

Steinberg, M. (1998). Tilting the frame: Considerations on collective action framing from a discursive turn. Theory and Society, 27 (6): 845-872.

Tarrow, S.G. (2004). Power in movement: Collective action, social movements and politics (previous reprinting in 1994, 1998, 2003). Cambridge University Press.

Tarrow, S.G. (2011). Power in movement: Social movements and contentious politics (previous two editions in 1994 and 1998). Cambridge University Press.

Taylor, V. (2000). Mobilizing for change in a social movement society. Contemporary Sociology, 29(1), 219-230. https://www.jstor.org/stable/2654946

Tilly, C. (2004). Social movements, 1768-2004. Paradigm Press.

Touraine, A. (2000). Can we live together? Equality and difference. Stanford University Press.

Vandevoordt, R., \& Fleischmann, L. (2021). Impossible Futures? The Ambivalent temporalities of grassroots humanitarian action. Critical Sociology,47(2), 187-202. https://biblio.ugent.be/publication/8675377/file/8675378.pdf

Whittier, N. (1995). Feminist generations. Temple University Press. 